\title{
PROPORSI SEPEDA MOTOR TERHADAP PENGGUNAAN RUANG PEJALAN KAKI
}

\author{
Dr. Effendi Prih Raharjo, MT \\ Dosen STTD \\ Jl. Raya Setu No. 89, Cibuntu, \\ Cibitung, Bekasi 17520 \\ Telp./Fax : (021) 8254640
}

\author{
Dessy Angga A, MT \\ Dosen STTD \\ J1. Raya Setu No. 89, Cibuntu, \\ Cibitung, Bekasi 17520 \\ Telp./Fax : (021) 8254640
}

\author{
Drs. Purnama Yahya \\ Dosen STTD \\ Jl. Raya Setu No. 89, Cibuntu, \\ Cibitung, Bekasi 17520 \\ Telp./Fax : (021) 8254640
}

\author{
Novitasari, M.Eng \\ Dosen STTD \\ Jl. Raya Setu No. 89, Cibuntu, \\ Cibitung, Bekasi 17520 \\ Telp./Fax : (021) 8254640
}

\author{
Sabrina Handayani, MT \\ Dosen STTD \\ Jl. Raya Setu No. 89, Cibuntu, \\ Cibitung, Bekasi 17520 \\ Telp./Fax : (021) 8254640
}

\begin{abstract}
ABSTRAKSI
Meningkatkan aksesibilitas pejalan kaki adalah kebijakan populer di negara-negara maju.Bertentangan dengan negara-negara maju, negara berkembang seperti Indonesia menganggap berjalan kaki merupakan kebiasaan yang tidak populer di daerah perkotaan. Hal ini dibuktikan di Kota Bekasi sebagai salah satu kota di Indonesia. Selain faktor internal dari pelaku pejalan kaki itu sendiri seperti: kemalasan, efisiensi waktu, dan faktor budaya; faktor eksternal juga berkontribusi terhadap masalah. Faktor-faktor eksternal seperti iklim, cuaca, polusi, dan fasilitas pejalan kaki yang tidak mendukung. Buruknya kondisi aksesibilitas pejalan kaki berkontribusi pada kurangnya minat masyarakat Bekasi dalam menggunakan transportasi umum.Oleh karena itu, banyak orang di Bekasi memilih untuk menggunakan angkutan pribadi daripada angkutan umum.

Meningkatkan walkability tidak memerlukan investasi modal yang besar seperti penggunaan moda transportasi lainnya. Aspek yang paling penting untuk meningkatkan aksesibilitas pejalan kaki adalah kondisi prasarana dan integrasi dengan fasilitas angkutan umum. Hal ini karena hampir semua aktivitas kehidupan manusia bertujuan untuk memindahkan orang dari satu tempat ke tempat lain dengan berjalan.

Dalam penelitian ini menganalisis kurangnya kesadaran pengguna sepeda motor yang mengorbankan fasilitas pejalan kaki untuk meningkatkan aksesibilitas dengan memaksa menggunakan trotoar untuk menghindari kemacetan dijalan raya. Selain itu kurangnya integrasi pejalan kaki dengan fasilitas angkutan umum yang kurang memadai sebagai sumber masalah transportasi di Bekasi.Terkait dengan itu, penelitian ini memberikan desain prasarana pejalan kaki sesuai dengan konsep Pedestrian Oriented Development (POD) dan New Urban Concept.
\end{abstract}

\begin{abstract}
Improving pedestrian accessibility is a popular policy in developed countries. In contrary with developed countries, developing countries such as Indonesia considers walking as a habit that is not popular in urban areas. It is evidenced in Bekasi as one of the cities in Indonesia. In addition to internal factors of the offender pedestrian itself like: laziness, time efficiency, and cultural factors; External factors also contribute to the problem. External factors such as climate, weather, pollution, and pedestrian facilities that do not support. The poor condition of pedestrian accessibility contribute to the lack of public interest in using the Bekasi Public Transportation .Therefore, many people in Bekasi choose to use private transport rather than public transport.
\end{abstract}


Improving walkability does not require large capital investments such as the use of other modes of transport. The most important aspect to improve pedestrian accessibility is a condition of the infrastructure and integration with public transport facilities. This is because almost all activities of human life aims to move people from one place to another by walking.

In this study, analyzes the lack of user awareness of motorcycles at the expense of pedestrian facilities to improve accessibility by forcing the use of the sidewalk to avoid congestion on the highway. Besides the lack of integration of passengers by public transport, facilities are inadequate as a source of transport problems in Bekasi. Associated with it, this study provides pedestrian infrastructure design in accordance with the concept of Pedestrian Oriented Development (POD) and the New Urban Concept.

\section{PENDAHULUAN}

\section{A. Latar Belakang Penelitian}

Transportasi berkelanjutan merupakan isu penting bagi banyak negara di dunia.Dampak ini mengakibatkan transportasi yang memaksa semua negara untuk mengembangkan strategi mobilitas yang berkelanjutan.aksesibilitas berkelanjutan adalah upaya tersebut menuju strategi transportasi yang berkelanjutan. Penelitian ini mengeksplorasi aspek penting untuk mengembangkan aksesibilitas berkelanjutan untuk meningkatkan walkability di satu wilayah. Tujuan penelitian ini adalah untuk memberikan rekomendasi dalam mencapai aksesibilitas yang berkelanjutan dengan meningkatkan aksesibilitas pejalan kaki untuk fasilitas transportasi umum di Bekas.Hasil penelitian ini diharapkan untuk mendapatkan wawasan yang lebih baik dengan mendapatkan pelajaran untuk aksesibilitas perbaikan pedestrian angkutan umum di Bekasi.Hasil penelitian menunjukkan beberapa hal yang mungkin menjadi dasar pertimbangan untuk meningkatkan kebijakan strategis saat ini di Bekasi. Diharapkan bahwa hal itu akan membantu Kota Bekasi untuk mengantisipasi masalah dalam pelaksanaan kebijakan strategis.

Meningkatkan aksesibilitas pejalan kaki adalah kebijakan populer di negara-negara maju.Bertentangan dengan negara-negara maju, negara berkembang seperti Indonesia menganggap berjalan kaki merupakan kebiasaan yang tidak populer di daerah perkotaan. Hal ini dibuktikan di Kota Bekasi sebagai salah satu kota di Indonesia. Selain faktor internal dari pelaku pejalan kaki itu sendiri seperti: kemalasan, efisiensi waktu, dan faktor budaya; faktor eksternal juga berkontribusi terhadap masalah. Faktor-faktor eksternal seperti iklim, cuaca, polusi, dan fasilitas pejalan kaki yang tidak mendukung. Buruknya kondisi aksesibilitas pejalan kaki berkontribusi pada kurangnya minat masyarakat Bekasi 
dalam menggunakan transportasi umum.Oleh karena itu, banyak orang di Bekasi memilih untuk menggunakan angkutan pribadi daripada angkutan umum.

Meningkatkan walkability tidak memerlukan investasi modal yang besar seperti penggunaan moda transportasi lainnya. Aspek yang paling penting untuk meningkatkan aksesibilitas pejalan kaki adalah kondisi prasarana dan integrasi dengan fasilitas angkutan umum. Hal ini karena hampir semua aktivitas kehidupan manusia bertujuan untuk memindahkan orang dari satu tempat ke tempat lain dengan berjalan.

Dalam penelitian ini menganalisis kurangnya kesadaran pengguna sepeda motor yang mengorbankan fasilitas pejalan kaki untuk meningkatkan aksesibilitas dengan memaksa menggunakan trotoar untuk menghindari kemacetan dijalan raya. Selain itu kurangnya integrasi pejalan kaki dengan fasilitas angkutan umum yang kurang memadai sebagai sumber masalah transportasi di Bekasi.Terkait dengan itu, penelitian ini memberikan desain prasarana pejalan kaki sesuai dengan konsep Pedestrian Oriented Development (POD) dan New Urban Concept.

\section{B. Rumusan Masalah}

Untuk memenuhi tujuan penelitian, penelitian ini akan mengeksplorasi pertanyaan sebagai berikut:

1. Berapa Jumlah proporsi sepeda motor yang menggunakan fasilitas pejalan kaki?

2. Berapa Jumlah demand pejalan kaki yang menggunakan fasilitas prasarana pejalan kaki?

3. Bagaimana integrasi pejalan kaki yang menggunakan fasilitas angkutan umum?

\section{Tujuan Penelitian}

Tujuan utama dari penelitian ini adalah untuk mengidentifikasi kemungkinan pendekatan untuk meningkatkan aksesibilitas pejalan kaki dari angkutan umum di Kota Bekasi, dalam konteks peningkatan aksesibilitas berkelanjutan. Tujuan khusus yang dijelaskan sebagai berikut:

1. Untuk mengetahui Jumlah proporsi sepeda motor yang menggunakan fasilitas pejalan kaki

2. Untuk mengetahui Jumlah demand pejalan kaki yang menggunakan fasilitas prasarana pejalan kaki

3. Untuk mengetahui desain prasarana pejalan kaki yang terintegrasi dengan fasilitas angkutan umum 


\section{STRATEGI DESAIN FASILITAS PEJALAN KAKI}

Hal terpenting ketika merencanakan fasilitas pejalan kaki adalah dengan menempatkan pejalan kaki sebagai bagian pengguna ruang jalan dalam satu sistem jaringan jalan. Desain fasilitas pejalan kaki dapat dibagi menjadi 3 pendekatan yaitu segregation (pemisahan), integration (penggabungan), dan separation (pembagian).

1. Segregation

Pendekatan ini memisahkan fasilitas pejalan kaki dengan jalan untuk kendaraan bermotor. Pendekatan ini banyak diaplikasikan pada perencanaan kota-kota modern, seperti jalan khusus untuk pejalan kaki (pedestrian only street).

2. Integration

Pendekatan ini didasarkan pada kondisi dimana pada kebanyakan lokasi di jaringan jalan antara pejalan kaki dan kendaraan bermotor harus berbagi ruang. Pada kondisi ini, kehati-hatian dalam manajemen lalu lintas sangat penting, seringkali konsekuensi terhadap pejalan kaki kurang diperhatikan. Contoh teknik pada pendekatan ini adalah menyediakan fase tersendiri untuk pejalan kaki pada persimpangan dengan lampu lalu lintas, pelican crossing, rambu, speed hump untuk mengurangi kecepatan, dan lain-lain.

3. Separation

Pendekatan ini bertujuan memisahkan pejalan kaki dengan kendaraan bermotor dengan dua dimensi waktu dan ruang. Pembagian waktu dapat berupa memberikan waktu tertentu kepada pejalan kaki untuk menggunakan ruang jalan dan kemudian diikuti kendaraan untuk waktu berikutnya. Contoh pembagian waktu adalah pelican crossing. Pembagian spatial memberikan pejalan kaki fasilitas dengan membagi sebagian ruang milik jalan untuk fasilitas pejalan kaki. Contoh pembagian spatial adalah trotoar.

Desain fasilitas pejalan kaki pada jalan arteri umumnya adalah:

1. Pelican (Pedestrian Light Control)

2. Pufin (Pedestrian User Friendly Intelligent)

\section{METODE PENELITIAN}

\section{A. Lokasi dan Waktu Penelitian}

Lokasi dalam penelitian Proporsi Sepeda Motor Terhadap Penggunaan Ruang Pejalan Kaki mencakup daerah Bulak Kapal, kecamatan Margahayu, Kota Bekasi. 


\section{B. Metodologi Penelitian}

Fokus penelitian ini adalah untuk meningkatkan aksesibilitas pejalan kaki ke fasilitas henti angkutan umum di Bekasi dan menjamin keselamatan pejalan kaki terhadap perilaku proporsi sepeda motor yang melewati trotoar. Karena kurangnya aksesibilitas pejalan kaki dari angkutan umum di Bekasi, orang di Bekasi tidak menempatkan begitu banyak minat untuk menggunakan transportasi umum. Kerangka teoritis bertujuan untuk memberikan gagasan tentang bagaimana meningkatkan walkability untuk mendapatkan fasilitas transportasi umum di kota Bekasi. Kerangka ini dikembangkan dengan melakukan review teoritis pada peningkatan walkability. Sebuah kerangka teori menjadi penting, karena merupakan dasar untuk menciptakan faktor kunci yang berhubungan dengan meningkatkan walkability. Kerangka desain penelitian dapat dilihat di bawah ini:

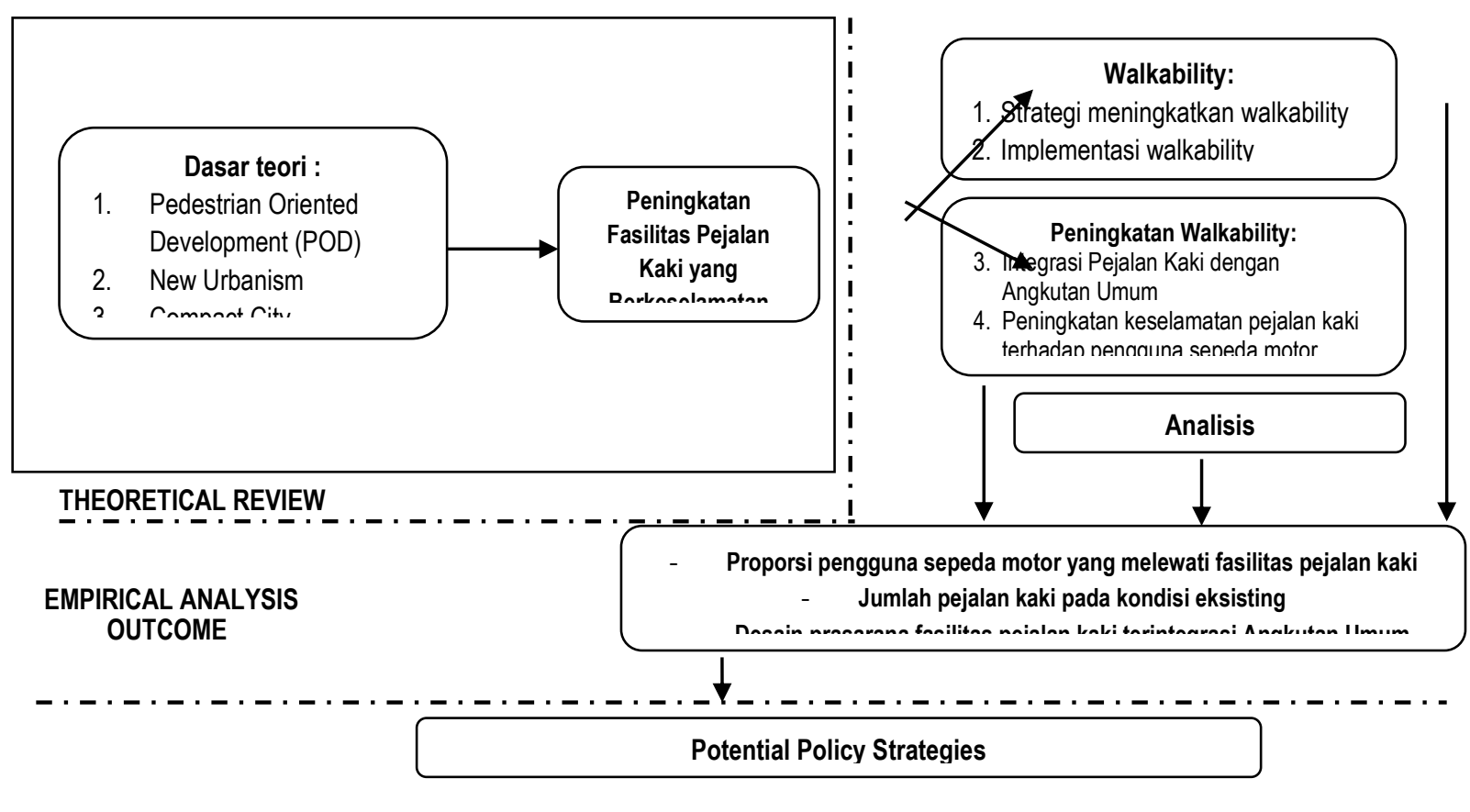

Bagan 3.1 Desain Penelitian

\section{ANALISIS DATA DAN PEMBAHASAN}

\section{A. KONDISI EKSISTING}

Masalah utama transportasi di Bekasi berasal dari kurangnya aksesibilitas pejalan kaki dari angkutan umum, sehingga orang lebih suka menggunakan pribadi daripada angkutan umum.Saat ini, di Bekasi trotoar sebagai sarana transportasi untuk pejalan kaki telah berubah menjadi fungsi ekonomi bagi masyarakat setempat. 
Banyak trotoar di Bekasi digunakan untuk kegiatan perdagangan dan tidak berfungsi sebagai fasilitas pejalan kaki untuk orang-orang.Banyak orang di Bekasi berjalan di situasi yang tidak nyaman.Sebagai konsekuensi, angkutan umum tidak menjadi pilihan bagi masyarakat.Gambar di bawah menggambarkan kondisi fasilitas halte bus yang telah berubah menjadi tempat untuk pengecer.Tentunya, kondisi ini menyebabkan ketidaknyamanan masyarakat untuk menggunakan transportasi umum.

Baru-baru ini, pemerintah daerah mencoba untuk mengubah citra Bekasi sebagai kota yang berkelanjutan. Salah satu upaya pemerintah daerah adalah meningkatkan walkability.Pemerintah daerah percaya bahwa polusi dan kemacetan dapat dikurangi dengan meningkatkan kendaraan tidak bermotor seperti berjalan dan bersepeda. Pemerintah daerah lebih menekankan pada berjalan dari bersepeda, karena pemerintah telah belajar dari kegagalan jalur sepeda di kota-kota lain di Indonesia. Misalnya, Bandung, salah satu kota besar di Indonesia, telah gagal dalam melaksanakan jalur sepeda. Selain itu, jalur sepeda di Kota Bandung digunakan oleh sepeda motor dan kendaraan lainnya (b2wchapterbandung, 2011).

Oleh karena itu, Pemerintah Daerah Bekasi lebih menekankan pada kaki, dan mencoba untuk meningkatkan walkability.Hal ini karena masalah besar angkutan umum di Bekasi berasal dari kurangnya aksesibilitas terutama pada kurangnya akses pejalan kaki bagi orang untuk pergi ke layanan transportasi umum. Akibatnya, penelitian ini berfokus pada bagaimana meningkatkan walkability orang di Bekasi, terutama untuk mencapai layanan transportasi umum.

\section{B. ANALISIS DATA SURVEI}

Dari kedua grafik diatas jumlah pejalan kaki tertinggi di Bekasi Timur (BTC) dalam waktu per 5 menit adalah 24 pejalan kaki yang menyusuri dan jumlah paling rendah adalah 8 pejalan kaki yang menyusuri jalan. Dan rata-rata pejalan kaki tiap menit adalah 3 orang pejalan kaki.

A. Jumlah pejalan kaki yang menyusuri di Bekasi Timur (BTC) (arah ke Bulak Kapal)

Dari data jumlah pejalan kaki tertinggi dalam waktu per 5 menit adalah 26 pejalan kaki yang menyusuri dan jumlah paling rendah adalah 11 pejalan kaki yang menyusuri jalan. Dan rata-rata pejalan kaki tiap menit adalah 2-3 orang pejalan kaki.

Data mengenai jumlah orang yang menyeberang sebagai berikut:

B. Analisis data pejalan kaki dan penyeberang di Bekasi Timur (BTC) (arah ke TOL Bekasi Timur): 
Dari data diatas dapat diketahui arus pejalan di Bekasi Timur (BTC) (arah ke TOL Bekasi Timur):

\section{$\frac{374 \text { Pejalan Kaki }}{120 \text { menit }}=3^{\text {pejalan } / \text { menit }}$}

C. Jumlah pejalan kaki yang menyusuri dan menyeberang di Bekasi Timur (BTC) (arah ke Bulak Kapal )

Rata-rata pejalan kaki per menit adalah:

$$
\frac{304 \text { Pejalan Kaki }}{120 \text { menit }}=2-3 \text { pejalan } / \text { menit }
$$

Analisis dan Pemecahan Masalah

Untuk menentukan tingkat kebutuhan fasilitas pejalan kaki yang dimaksud digunakan metode - metode yang mungkin terjadi antara pejalan kaki dengan arus lalu lintas kendaraan.

A. Kebutuhan Fasilitas Penyeberangan

Untuk menentukan kebutuhan fasilitas penyeberangan digunakan rumus sebagai berikut :

$$
\mathrm{P} \times \mathrm{V}^{2}
$$

Dimana :

$\mathrm{P}=$ Pejalan kaki yang menyeberang jalan/jam

$\mathrm{V}=$ Volume kendaraan tiap jam dalam dua arah (kend/jam)

1. Jumlah Pejalan Kaki yang menyeberang pada wilayah studi pada waktu survai yang ditentukan, yaitu pada pukul 06.00-08.00 WIB, sebagai berikut :

2. Rekomendasi pemilihan jenis penyeberangan :

B. Kebutuhan Fasilitas Trotoar

Kebutuhan trotoar menurut penggunaan lahan. Untuk menentukan lebar trotoar yang dibutuhkan pejalan kaki, kita dapat melihat table berikut :

Untuk menentukan tingkat kebutuhan fasilitas yang dimaksud digunakan metode metode yang mungkin terjadi antara pejalan kaki dengan arus lalu lintas kendaraan. Hal tersebut dengan memperhatikan pula karakteristik pejalan kaki.

Untuk mengetahui kebutuhan lebar trotoar yang dipergunakan dengan menggunakan rumus :

$$
\begin{aligned}
\mathrm{Wd}=(\mathrm{P} / 35) & +\mathrm{N} \\
\text { Dimana }: \mathrm{Wd} & =\text { Lebar trotoar yang dibutuhkan } \\
\mathrm{P} & =\text { Arus pejalan kaki per menit } \\
\mathrm{N} & =\text { Kostanta }
\end{aligned}
$$


Untuk menentukan nilai $\mathrm{N}$ dipengaruhi oleh keadaan lingkungan disekitar fasilitas pejalan kaki tersebut.

Jumlah pejalan kaki yang menyusuri jalan tiap wilayah studi :

Jadi perhitungannya adalah sebagai berikut :

Lebar Trotoar untuk ruas Arah ke TOL Bekasi Timur :

$$
\begin{aligned}
\mathrm{P} & =374 \mathrm{pj} \ln / \mathrm{jam} \\
& =3,1 \mathrm{pjln} / \text { menit } \\
\mathrm{Wd} & =\mathrm{P} / 35+\mathrm{N}=3,1 / 35+1,5=1,588 \text { meter }
\end{aligned}
$$

Menurut perhitungan besar trotoar yang dibutuhkan adalah sebesar $=1,588$ meter Lebar Trotoar untuk Arah Ke Bulak Kapal:

$$
\begin{aligned}
\mathrm{P} & =304 \mathrm{pjln} / \mathrm{jam} \\
& =2,5 \mathrm{pjln} / \text { menit } \\
\mathrm{Wd} & =\mathrm{P} / 35+\mathrm{N}=2,5 / 35+1,5=1,571 \text { meter }
\end{aligned}
$$

Menurut perhitungan besar trotoar yang dibutuhkan adalah sebesar $=1,571$ meter

\section{KEDUDUKAN JARINGAN FASILITAS PEJALAN KAKI}

Fasilitas pejalan kaki harus menjadi bagian yang terintegrasi dalam rencana tata ruang wilayah kabupaten/kota. Untuk menyediakan ruang pejalan kaki tersebut, perlu disusun:

a. Rencana Detail Tata Ruang (RDTR) dan peraturan zonasi untuk mengatur ketentuan teknis yang terkait dengan penyediaan infrastruktur kota atau kawasan yang akan dikembangkan.

b. Rencana Tata Bangunan dan Lingkungan (RTBL) yang merupakan panduan rancang bangun suatu lingkungan/kawasan yang dimaksudkan untuk mengendalikan pemanfaatan ruang dan memuat materi pokok ketentuan program bangunan dan lingkungan, rencana umum, dan panduan rancangan, rencana investasi, ketentuan pengendalian rencana, dan pedoman pengendalian pelaksanaan pengembangan lingkungan/kawasan.

c. Untuk perencanaan yang bersifat privat atau semi privat; misalnya dalam lingkungan kawasan permukiman baru, maka pengembang harus sudah mempersiapkan ruang pejalan kaki dalam rancangan siteplan, sebelum mendapatkan izin lokasi.

d. Untuk perencanaan yang bersifat revitalisasi kawasan atau rehabilitasi lingkungan, maka rancangan penyediaan ruang pejalan kaki sudah harus dicantumkan dalam siteplan kawasan revitalisasi.

\section{Kriteria Kawasan yang Diprioritaskan}


Penyediaan fasilitas pejalan kaki diprioritaskan untuk dikembangkan pada:

a. Kawasan perkotaan dengan tingkat kepadatan penduduk tinggi;

b. Jalan-jalan yang memiliki rute angkutan umum yang tetap;

c. Kawasan yang memiliki aktivitas yang tinggi, seperti pasar dan kawasan bisnis/komersial, dan jasa;

d. Lokasi-lokasi dengan tingkat mobilitas tinggi dan periode yang pendek, seperti stasiun, terminal, sekolah, rumah sakit, dan lapangan olah raga;

e. Lokasi yang mempunyai mobilitas yang tinggi pada hari-hari tertentu, misalnya lapangan/gelanggang olah raga dan tempat ibadah.

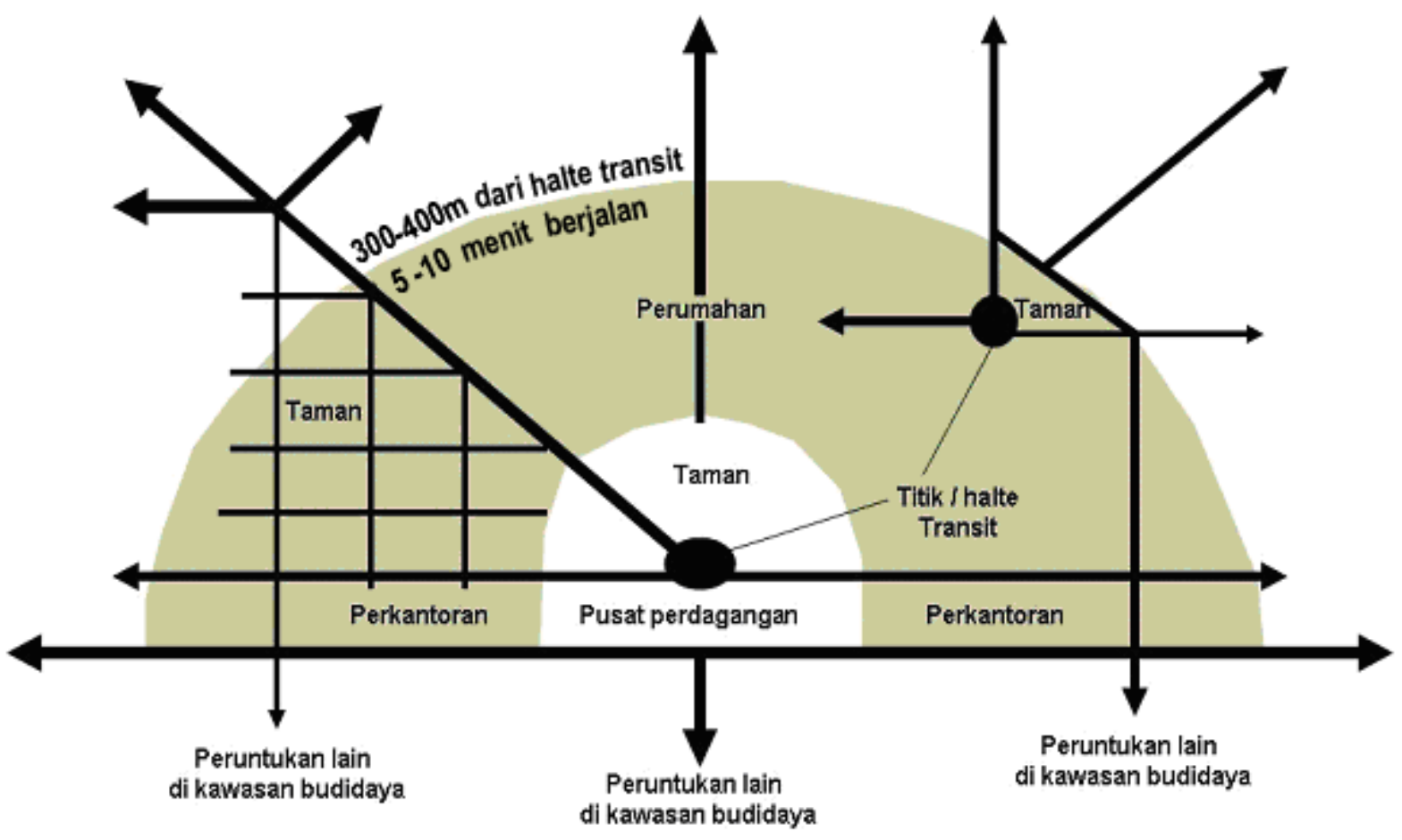

\section{Pola Sirkulasi Pejalan Kaki}

a. Fasilitas pejalan kaki harus memiliki hirarki penggunaan. Pada umumnya berawal dari satu titik ke titik lainnya seperti dari rumah ke kantor atau lokasi tujuan akhir dan sebaliknya.

b. Fasilitas pejalan kaki sebagai jalur utama harus memiliki sarana dan prasarana untuk membantu mobilitas, seperti ram pejalan kaki untuk memberikan kenyamanan dalam berjalan dan memandu para difable untuk dapat dengan mudah melintas.

c. Untuk menghubungkan fasilitas pejalan kaki yang berseberangan dibangun jembatan penyeberangan dan penyeberangan sebidang. 
d. Perlu tersedia titik-titik yang menghubungkan fasilitas pejalan kaki dengan moda transportasi seperti halte atau shelter kendaraan umum.

e. Penyediaan fasilitas sarana dan prasarana fasilitas pejalan kaki, harus disesuaikan dengan kebutuhan.

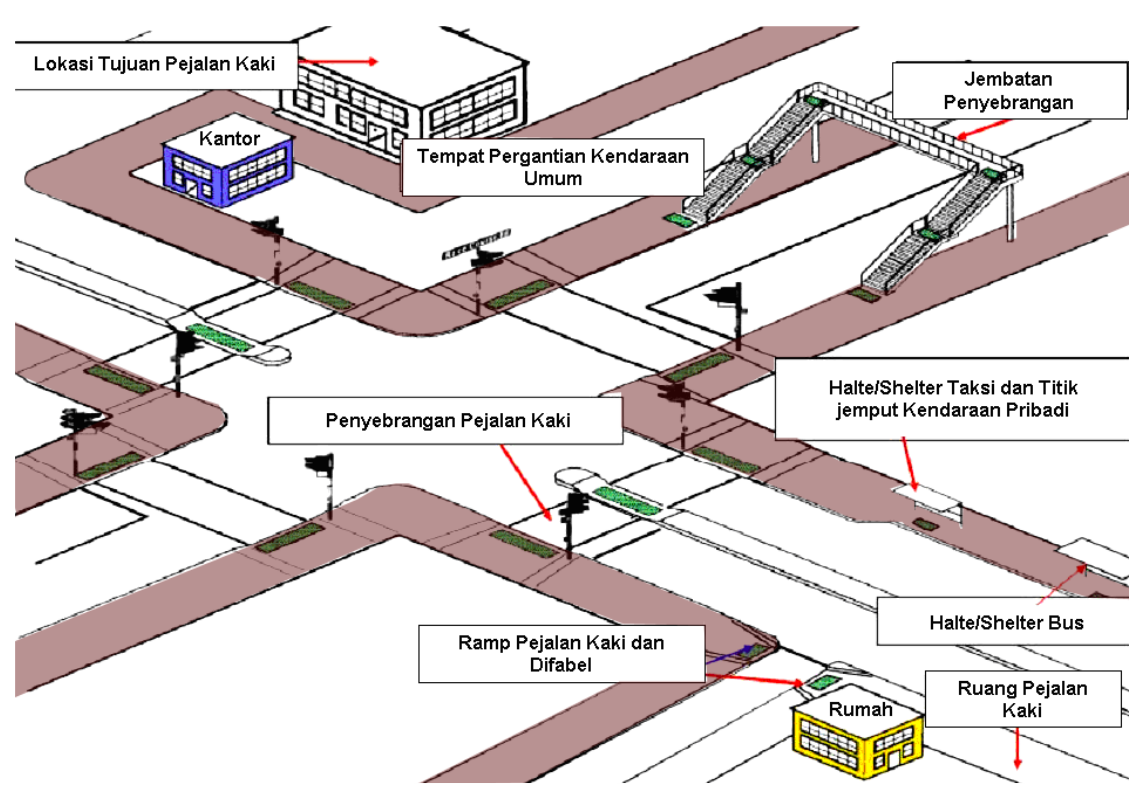

\section{Sistem Hirarki Prasarana dan Sarana pada Fasilitas Pejalan Kaki}

a. Standar penyediaan pelayanan fasilitas pejalan kaki sangat bervariasi, ukuran dan dimensinya tergantung dari tingkat pelayanan (level of service) dan tingkat volume pergerakan di fasilitas pejalan kaki.

b. Penyediaan sarana dan prasarana fasilitas pejalan kaki tergantung pada tipologi fasilitas pejalan kaki. Tipologi ini disesuaikan dengan peruntukan ruang di kawasan terkait.

\section{FUNGSI FASILITAS PEJALAN KAKI}

Fasilitas pejalan kaki dapat ditinjau dari dua aspek yaitu aspek pejalan kaki dan aspek lalu lintas kendaraan. Dari dua aspek ini, fasilitas pejalan kaki memiliki fungsi masing-masing sebagai berikut :

a) Fungsi fasilitas pejalan kaki bagi bagi pejalan kaki adalah untuk memberi kesempatan bagi lalu lintas orang ketika menyusur jalan dan/atau menyeberang jalan, sehingga dapat berpapasan pada masing-masing arah atau menyiap dengan rasa aman dan nyaman. 
b) Fungsi fasilitas pejalan kaki bagi lalu lintas kendaraan adalah untuk menghindarkan terjadinya konflik dengan pejalan kaki dan/atau konflik yang terjadi akibat bercampurnya para pejalan kaki dengan kendaraan.

Fasilitas pejalan kaki direncanakan berdasarkan ketentuan-ketentuan sebagai berikut :

1) Pejalan kaki harus mencapai tujuan dengan jarak sedekat mungkin, aman dari lalu lintas yang lain dan lancar.

2) Terjadinya kontinuitas fasilitas pejalan kaki (menerus), yang menghubungkan daerah yang satu dengan yang lain dengan langsung, dan selurus/sependek mungkin.

3) Apabila jalur pejalan kaki memotong arus lalu lintas yang lain harus dilakukan pengaturan lalu lintas, baik dengan lampu pengatur ataupun dengan marka penyeberangan, atau tempat penyeberangan yang tidak sebidang. Jalur pejalan kaki yang memotong jalur lalu lintas berupa penyeberangan (Zebra Cross), marka jalan dengan lampu pengatur lalu lintas (Pelican Cross), jembatan penyeberangan dan terowongan.

4) Fasilitas pejalan kaki harus dibuat pada ruas-ruas jalan di perkotaan atau pada tempat-tempat dimana volume pejalan kaki memenuhi syarat atau ketentuanketentuan untuk pembuatan fasilitas tersebut.

5) Jalur pejalan kaki sebaiknya ditempatkan sedemikian rupa dari jalur lalu lintas yang lainnya, sehingga keselamatan pejalan kaki lebih terjamin.

6) Dilengkapi dengan rambu atau pelengkap jalan lainnya, sehingga pejalan kaki leluasa untuk berjalan, terutama bagi pejalan kaki yang tuna daksa.

7) Perencanaan jalur pejalan kaki dapat sejajar, tidak sejajar atau memotong jalur lalu lintas yang ada.

8) Jalur pejalan kaki harus dibuat sedemikian rupa sehingga apabila hujan permukaannya tidak licin, tidak terjadi genangan air (kering) serta disarankan untuk dilengkapi dengan pohon-pohon peneduh.

9) Untuk menjaga keamanan dan keleluasaan pejalan kaki, harus dipasang kerb jalan sehingga fasilitas pejalan kaki lebih tinggi dari permukan jalan.

10) Fasilitas pejalan kaki harus menjamin rasa aman bagi pejalan kaki selama berjalan pada jalurnya sendiri maupun dalam hubungannya dengan sistem jaringan lalu lintas.

11) Fasilitas pejalan kaki harus dibuat dengan tanda yang mudah dan cepat dikenali oleh pejalan kaki maupun pengemudi kendaraan. 
Disamping memenuhi ketentuan umum, fasilitas pejalan kaki dapat dipasang dengan kriteria sebagai berikut :

1) Fasilitas pejalan kaki harus dipasang pada lokasi-lokasi dimana pemasangan fasilitas tersebut memberikan manfaat yang maksimal, baik dari segi keamanan, kenyamanan ataupun kelancaran perjalanan bagi pemakainya.

2) Tingkat kepadatan pejalan kaki, atau jumlah konflik dengan kendaraan dan jumlah kecelakaan harus digunakan sebagai faktor dasar dalam pemilihan fasilitas pejalan kaki yang memadai.

3) Pada lokasi-lokasi/kawasan yang terdapat sarana dan prasarana umum.

4) Fasilitas pejalan kaki dapat ditempatkan disepanjang jalan atau pada suatu kawasan yang akan mengakibatkan pertumbuhan pejalan kaki dan biasanya diikuti oleh peningkatan arus lalu lintas serta memenuhi syaratsyarat atau ketentuanketentuan untuk pembuatan fasilitas tersebut.

Fasilitas pejalan kaki yang formal terdiri dari beberapa jenis sebagai berikut :

1. Jalur Pejalan Kaki yang terdiri dari :

a) Trotoar

b) Penyeberangan

a. Jembatan penyeberangan

b. Zebra cross

c. Pelican cross

d. Terowongan

c) Non Trotoar

2. Pelengkap Jalur Pejalan kaki yang terdiri dari :
a) Lapak tunggu
b) Rambu
c) Marka
d) Lampu lalu lintas
e) Bangunan pelengkap 


\section{E. DESAIN USULAN FASILITAS PEJALAN KAKI}

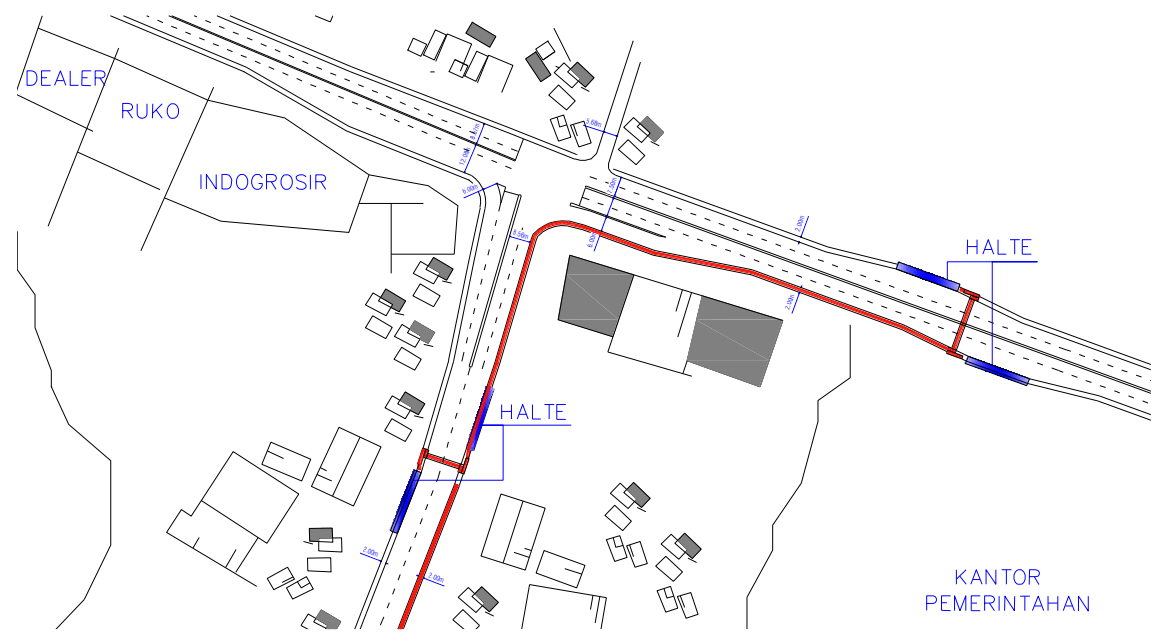

Gambar Desain Usulan Jembatan Penyeberangan Orang Bulak Kapal

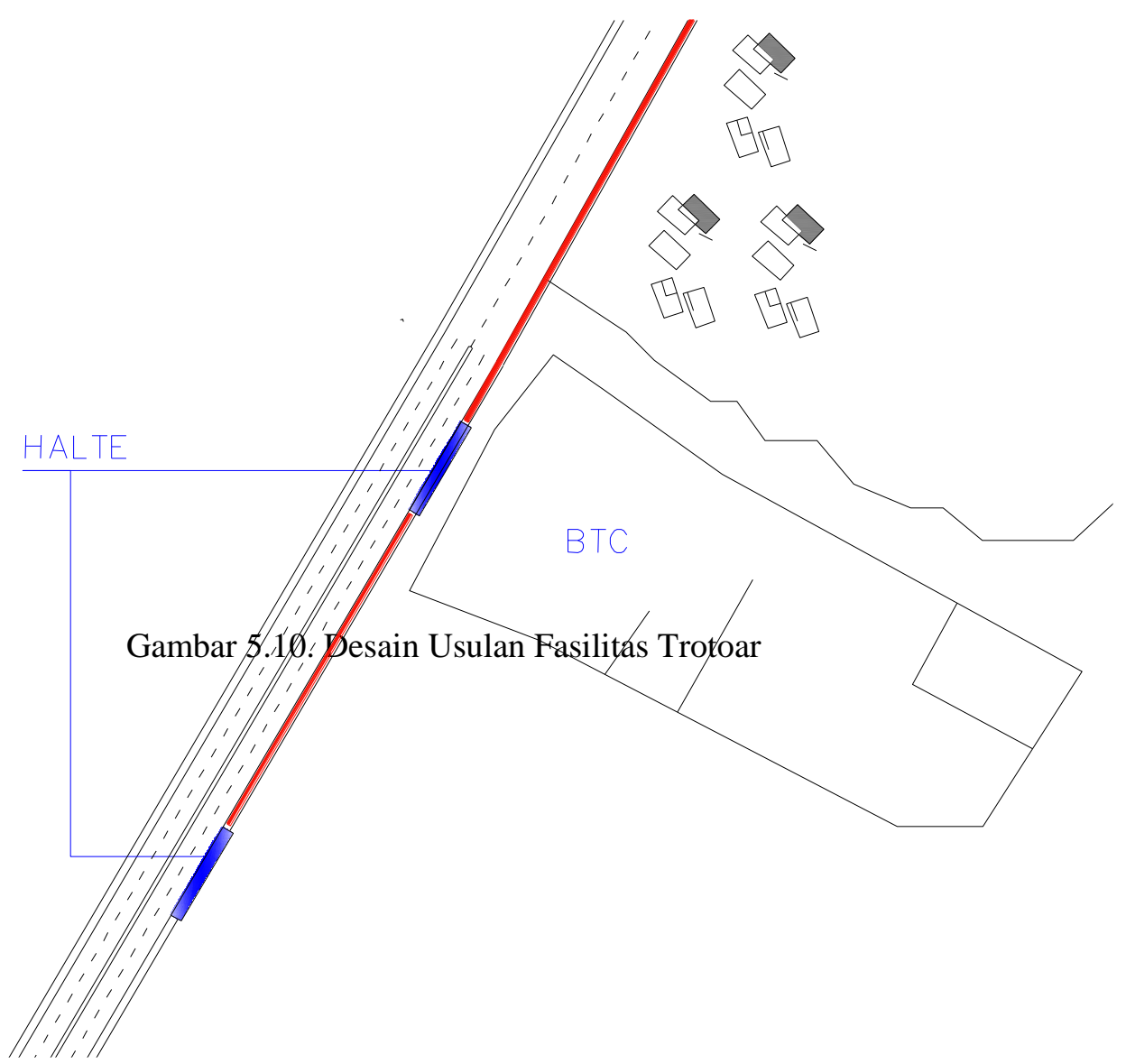




\section{DAFTAR PUSTAKA}

Akbar, N. (2001). Pemodelan Sistem Informasi Geografis Untuk Penentuan Nilai Lahan. Skripsi. Teknik Geodesi ITB. Bandung

American Planning Association.(2002). Policy Guide on Smart Growth. Ratified April 15.http://www.planning.org/policyguides/pdf/smartgrowth.pdf

Bekasi Dalam Angka. (2011). Data Primer Kota Bekasi. Badan Perencanaan Pembangunan Daerah Kota Bekasi

BSTP.(2011). Dokumen Panduan Perencanaan Jalan Kaki. Direktorat Bina Sistem Transportasi Perkotaan. Kementerian Perhubungan Republik Indonesia

Burton, E. (2000). The Compact City: Just or Just Compact? A Prelimanary Analysis. Urban Studies 37 (11): 1996-2001

DETR. (1998a). A New Deal for Transport: Better for Everyone: Transport White Paper. The Stationery Office, London

IHT. (1997). Transport in the Urban Environment. The Institution of Highways \& Transportation. London

May, A. (2001). Transport Policy. In: O'Flaherty C. A. Ed (2001) Transport Planning and Traffic Engineering. Pp. 42-79. Butterworth Heinemann, Oxford

Planning and Designing for Pedestrian : Guideline. (2012). Department for Transport, London-UK

Shay, E., Spoon, S.C., Khattak, A.J. (2003).Walkable Environments and Walking Activity. Final Report for

Southworth, M. (2005).Designing the Walkable City.Journal of Urban Planning and Development. Pp 246-257

UNDIP. (2012). Perencanaan wilayah Kota. Semarang, Indonesia. http://www.pwk.ft.undip.ac.id 